\title{
Drive and incentive combinations during acquisition, shift and extinction'
}

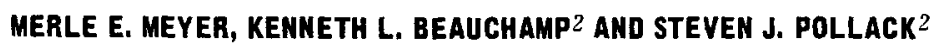

WHITMAN COLLEGE

For 16 days, rats received 1 trial a day training in a straight runway with either 3 or $23 \mathrm{hr}$. of food deprivation (D) and $.2 \mathrm{gm}$ or $.8 \mathrm{gm}$ of food incentive $(\mathrm{K})$. This training was followed by $\mathrm{D}$ and $\mathrm{K}$ shift for 32 days and 16 days of extinction. Significant differences were obtained for $D$ and $\mathrm{K}$; however, the $\mathrm{D} \times \mathrm{K}$ interaction was not significant. The $D$ and $K$ shifts suggest some stability of performance over time, and the $D$ and $K$ were related to rates of extinction.

The combination of drive and incentive has been subject to considerable research in light of Hull's (1952) and Spence's (1956) formulations (Black, 1965). The present study investigated the relation between two levels of drive, two levels of incentive, and the interaction between these variables, as well as the "temporary" nature of the drive and incentive shift and the rate of extinction.

Subjects

The Ss were 80 experimentally naive, male albino rats, approximately 90 days old at the beginning of the experiment.

\section{Apparatus}

The apparatus was a simple flat black, $60 \mathrm{in}$. straight runway box. The first $10 \mathrm{in}$. served as a starting box and was separated from the remainder of the box by a sliding door. A white food cup was placed 2 in. from the opposite end of the apparatus and a second sliding door was placed 16 in. in front of this food cup. Two infra-red photocells and timers were used, one cell $1 / 4$ in. in front of the starting box and the other cell over the food cup. When the door of the starting box was raised it closed a circuit and activated one timer. The S's breaking the beam of the first cell activated a second timer, and the $S$ in breaking the beam of the second cell over the food cup stopped both timers. Thus, the total, start box, and runway latencies were measured.

\section{Procedure}

For the first three days each $\mathbf{S}$ was handled by the Es for $3 \mathrm{~min}$. perday. During this period the Ss had free access to food and water. The Ss were then divided on the basis of equal median weight into two groups, A and $\mathrm{B}$, of $40 \mathrm{Ss}$ each. The following five days Group A was placed on a $3 \mathrm{hr}$. food deprivation schedule $\left(D_{3}\right)$ and Group $B$ on a $23 \mathrm{hr}$. food deprivation $\left(\mathrm{D}_{23}\right)$. On the following two days, the deprivation was continued, but each $\mathrm{S}$ was allowed $5 \mathrm{~min}$, of free exploration of the maze.

Groups $A$ and $B$ were then divided into subgroups $\left(\begin{array}{lllllll}A_{1} & \& & A_{2} & \text { and } & B_{1} & \& & B_{2}\end{array}\right)$ of $20 \mathrm{ss}$ each. For 16 days each $S$ was given one trial a day training in the runway with $A_{1}$ receiving an incentive of $.2 \mathrm{gm}$ or $\left(\mathrm{K}_{.2}\right)$, and $\mathrm{A}_{2}$ an incentive of $.8 \mathrm{gm}(\mathrm{K} .8), \mathrm{B}_{1} .2 \mathrm{gm}$, and $\mathrm{B}_{2}$ $.8 \mathrm{gm}$. The $\mathrm{K}$ was a single pellet of food weighing the specified amount. The following day each subgroup was again divided into groups of five Ss each for a total of 16 groups. Four of these groups served as controls, i.e., $A_{1 a}\left(D_{3} K_{.2}\right)$ and the remaining 12 groups underwent either a shift of $K$, or $D$, or both, i.e., $A_{1 b}$ $\left(D_{3} K_{.8}\right), A_{1 c}\left(D_{23} K_{.2}\right), A_{1 d}\left(D_{23} K_{.8}\right)$. For 32 days each $\mathrm{S}$ was given one trial a day under this new schedule. The last 16 days, the Ss ran one non-reinforced trial a day under the food deprivation schedule used during the shift. In all cases the total latency criterion of 2 min. was used as the maximum response time. Results and Discussion

Total latencies for the last day of the acquisition period indicated that the large $K$ groups ran significantly faster than the small $\mathrm{K}$ groups $(\mathrm{F}=4.01, \mathrm{df}=1 / 76$, $\mathrm{p}<.05$ ). However, the greatest difference was obtained between the two measures of drive with Ss under the greater drive level running faster $(F=16.62$, $\mathrm{df}=1 / 76$, $p<.001)$. The interaction of $K$ and $D$ was found to be non-significant $(\mathrm{F}<1.00)$; thus there is no differential effect between the two variables. The data from the runway and start box latencies are compatible with the total latencies with the exception that there are no differences between the start box latencies for the $\mathrm{K}$ variable. These general results are consistent with those reported in the literature and support Spence's drive and incentive formulation.

At the end of the 32 days following the $\mathrm{D}$ and $\mathrm{K}$ shifts, the results from the total latencies revealed a yet greater significant difference between the drive levels than during the acquisition trials $(F=21.18$, $\mathrm{df}=1 / 76, \mathrm{p}<.0001$ ). This may be accounted for by the fact that the low drive groups at the end of the shift period were running significantly slower than at the end of the acquisition period and that the high drive groups were running at approximately the same speed. Nonsignificant differences were observed between the $K$ levels $(F=1.62, d f=1 / 76, p<.05)$ and the drive and incentive interaction $(F<1.00)$. These data suggest that the $\mathrm{K}$-shift effects may be temporary, and that such temporary effects occur when the drive level is low. Both runway and start box latencies lead to the same general conclusion as the total latency data.

On the final trial of the extinction period, the total latencies signify a significant difference between the drive levels $(F=7.41$, df $=1 / 76, p<.05)$. The latencies 
for the low drive level increased but the greatest change occurred for the high drive groups. As with the shift data, no significant differences were obtained for the $\mathrm{K}$ variable $(F<1.00)$ nor for the interaction $(F<1.00)$. Other latency measures yield similar conclusions.

\section{References}

Black, R. W. On the combination of drive and incentive motivation. Psychol. Rev., 1965, 72, 310-317.
Hull, C. L. A behavior system. New Haven: Yale University Press, 1952.

Spence, K. W. Behavior theory and conditioning. New Haven: Yale University Press, 1956.

\section{Notes}

1. This research was supported by research grant M-6474A from the National Institute of Mental Health, United States Public Health Service to the senior author.

2. Now at the Department of Psychology, Claremont Graduate School. 